\title{
Age Segmentation for Predicting Behavioural Intention of Using Railway Services in Indonesia
}

\author{
Savira Miranti Ansory* and Anya Safira
}

\begin{abstract}
Manuscript type: Research paper.

Research aims: This study aims to examine the predictors of passengers' behavioural intention in using railway services. It also attempts to identify whether these predictors differ among consumers of different age groups.

Design/ Methodology/ Approach: A survey is conducted to collect data from the passengers using the KA Commuter Line (KRL) Jabodetabek. The 213 respondents are divided into two age segmentations comprising young and old. Data are analysed separately. The proposed model is tested quantitatively through multiple regression analysis and the independent sample t-test.

Research findings: The results show that different age groups have different evaluations and they use different determinants for gauging the railway services. Perceived value emerges as an important determinant of customer satisfaction among the younger age group whereas service quality is the determinant for the older age group. Both groups, however, consider corporate image and customer satisfaction as determinants of behavioural intention.

Theoretical contributions/ Originality: This paper contributes to existing research on public transportation from a marketing perspective. It extends on previous works by adopting age segmentation to examine passengers' perception, evaluation and behavioural intention of using the railway services in Jakarta.
\end{abstract}

* Corresponding author: Savira Miranti Ansory is a PhD Candidate at the Cardiff Business School, Cardiff University, CF103EU, Cardiff, United Kingdom. Email: AnsorySM@cardiff. ac.uk

Anya Safira is a Lecturer at the Faculty of Economics and Business, Universitas Indonesia, 16424, Depok, Indonesia. Email: anyasafira@ui.ac.id 
Practitioner/ Policy implications: The findings of this study suggest that the Indonesian Railway Company should take age segmentation as a meaningful and useful social categorisation. It should not treat the entire population of passengers to be the same. Different age groups have different responsiveness and expectations of the railway services thus, the Indonesian Railway Company needs to put in more efforts in maintaining and improving its corporate image so as to encourage more people to use its services thereby reducing traffic congestion in Jakarta.

Research limitation: This study is limited by its sample size. Therefore, it is not possible to perform structural equation modelling (SEM).

Keywords: Behavioural Intention, Railway Services, Age Segmentation, Customer Satisfaction, Corporate Image.

JEL Classification: M3

\section{Introduction}

Jakarta, as the capital city of Indonesia, is facing a serious traffic congestion problem that has thus far, remained unsolved. A survey of the Castrol Magnatec Start-Stop found that Jakarta ranks as the world's most traffic-congested city (Wardhani \& Budiari, 2015). This is the consequence of Jakarta's high annual motor vehicle growth which has not been complemented by road developments, whether in number or in size. The current growth rate of road constructions in Jakarta is only about one per cent as compared to 12 per cent of private vehicle ownership (Ramadhan, 2015). If this situation continues, it is predicted that Jakarta will experience total congestion by the year 2020. According to Ramadhan (2015), the number of motor vehicles in 2014 was 17.5 million units with 75 per cent of these vehicles being motor cycles and 18 per cent being private cars. The remainders were public modes of transportation such as freight cars and special vehicles. These statistics suggest that road congestion has become an alarming phenomenon in Jakarta. Harmadi, Yudisthira and Koesrindartono (2015) proposes that congestion in Jakarta could lead to economic inefficiency due to the increase in travel time. The longer travel time caused by the time lost in traffic affects the individual's life in several ways. First, it adds to the fuel costs. Second, it alleviates productivity. Third, it causes missed opportunities and finally, it contributes to air pollution which then increases public health concerns. All of these can slow down the economic growth and development of Jakarta. 
The traffic congestion issue in Jakarta has triggered a number of reforms. For instance, the government has turned to developing mass public transportations to ease the public's mode of transportation. This includes the KA Commuter Line Jabodetabek, the Mass Rapid Transit (MRT), the Light Rapid Transit (LRT), and the Transjakarta busway. There were also some efforts to develop road networks and to establish policies with regards to road pricing and other aspects of macro transportation. Despite all these attempts, traffic congestion seems to have worsened. This is evidenced by the plummeting ratio of public transportation users in the last ten to fifteen years, depreciating from 56 per cent to between 20 and 25 per cent in 2014 (Jannah, 2014). Many people in Jakarta seem to prefer travelling by private vehicles or motorcycles in particular rather than public transportation. Gaduh, Gracner and Rothenberg (2017) noted that the commuting patterns in Jakarta cannot be explained by the changes that emerged in the fare costs which have remained low and flat. This shows that people are moving away from using public transportation. The weak indication of ridership could have been triggered by various factors. An earlier study conducted by Khafian (2013) emphasised that people view public transportation to be an unreliable mode of transportation for a number of reasons. One of these is the lack of vehicles servicing the public, next is the safety of the passengers while riding these public transportations followed by the punctuality schedule and the lack of comfort offered by public transportation. It was also unravelled by Khafian (2013) that motorcycle use was 38 per cent more efficient than public transportations.

The pervasive problem of road congestion has drawn the attention of various academic researchers. From the economic perspective, this issue has been investigated by Harmadi et al. (2015) who observed the willingness of the people in Jakarta to compensate in terms of money for averting traffic congestion. Their study noted that on average, 17 per cent of the private car users were willing to pay additional costs to avoid traffic congestion. In relation to this, 80 per cent of the motorcycle users were willing to pay not more that IDR100,000 per month for additional transportation costs to avert traffic congestion. Regular trains and bus commuters in general, were willing to pay an additional transportation cost of less than IDR100,000 per month for the same intent. All these additional costs represent the passengers' willingness to compensate in monetary terms for better public transportation provided by the government, as a way of reducing traffic congestion. From the 
social science perspective, Khafian (2013) suggested that sustainable transportation policy can be a part of the solution for overcoming the traffic congestion problem in Jakarta. Existing studies (Harmadi et al., 2015; Khafian, 2013; Gaduh et al., 2017) have provided some useful insights into the congestion problem in Jakarta but these are limited in scope. To the best of the authors' knowledge, little work has been done to explore this issue from the consumer's behavioural perspective.

Within the context of public transportation, consumer behaviourism has been well used as an underlying perspective to evaluate the service quality dimensions (e.g. De Ona, De Ona, Eboli, \& Mazzulla, 2015; Cavana, Corbett, \& Lo, 2007; Prasad \& Shekhar, 2010; Irfan, Kee, \& Shahbaz, 2012). Some researchers (Brons, Givoni, \& Rietveld, 2009; Rahaman \& Rahaman, 2009; Geetika \& Shefali, 2010; Chou, Kim, Kuo, \& Ou, 2011; Eboli \& Mazzulla, 2012) also focussed on examining the relationship between service quality and customer satisfaction. Despite these, the theories, concepts and practices developed in other countries may not necessarily be applicable to Indonesia, specifically Jakarta. Gaduh et al. (2017) have observed that communities in Jakarta city may react differently due to the different transportation routes and infrastructure, values, tastes, demographic compositions of households, income and commuting behaviour. Therefore, it is imperative to investigate this issue from the perspective of the Jakartan consumers.

As a developing country, Indonesia has an urbanisation process that is growing rapidly. This process however, is often associated with people growth and the development of clustering industries in cities. Consequently, this leads to significant traffic congestion. This paper takes Jakarta as the focus because it is one of the world's largest agglomeration, with a total population of more than 31 million. In this regard, the city is also acknowledged as having the worst traffic problem in the world (Gaduh et al., 2017). The KA Commuter Line Jabodetabek was chosen because its services are seen to be one of the possible solutions to ease the increasing traffic in the Greater Jakarta area (Jakarta, Bogor, Depok, Tangerang, and Bekasi - commonly abbreviated as Jabodetabek). The services are managed by the Indonesian Railway Company, a state-owned public company. The company is the single provider of railway services in the Greater Jakarta area. The subsidiary was formed in 2008 as an attempt to provide better services to the passengers of the KA Commuter Line (KRL) Jabodetabek.

For the purpose of predicting the behavioural intentions of the consumers, this study developed a model which incorporates service 
quality, perceived value, corporate image and customer satisfaction. This model was tested into two age segmentations using regression analysis. To date, the Indonesian Railway Company has not made any effort to segment their consumers. This research thus attempts to examine whether age segmentation is a viable method of segmentation for the KA Commuter Line (KRL) Jabodetabek users. Prior studies (Parahoo, Harvey, \& Radi, 2014) have shown that age has a significant impact on consumption patterns. Age can also influence passengers' service utilisation. Therefore, the importance of age is discussed in this study. The respondents were divided into two age segmentations: 29 years old and above and below 29 years old. The age of 29 acts as the cut-off age because it represents the median age of the Indonesian population (Central Intelligence Agency, 2014).

This study is believed to benefit the Indonesian Railway Company decision makers and the Indonesian government. An understanding of the passengers' behaviour from the perspective of marketing could facilitate strategic decisions that would increase communities' intention to use the KA Commuter Line (KRL) Jabodetabek. It is hoped that the increased use of public transportation (in this case, KA Commuter Line (KRL) Jabodetabek) can reduce the utilisation of private vehicles thereby reducing traffic congestion and air pollution.

The rest of this paper is organised as follows. Section 2 reviews prior literature on theoretical background and hypotheses development. Section 3 explains the research method. Section 4 presents and discusses the findings and Section 5 concludes the paper.

\section{Literature Review and Hypotheses Development}

\subsection{Behavioural Intention and Service Quality}

Behavioural intention is the extent of a person's desire to act in a certain behaviour (Fishbein \& Ajzen, 1975). It measures how hard an individual tries and the effort he/she plans to exert in order to perform the behaviour. Behavioural intention is an important outcome of service quality that is experienced at the time of the service encounter. An individual who experiences acceptable or good service quality is more likely to be satisfied and to possess a favourable behavioural intention towards buying or using a certain service. The individual may also engage in giving others more encouragement to buy/use the same service through word-of-mouth. A positive feedback from such 
individuals will not only determine the likeliness of their purchasing decision but also influence others.

Based on the above explanation, it can be deduced that examining the behavioural intention of public transportation's passengers is an important issue (Hsiao \& Yang, 2010). Doing so can help to increase the use of public transportations and reduce the number of private vehicles on the road. This can help to alleviate the level of traffic congestion that is currently pervasive. Only a few studies (Liu \& Liao, 2010) have examined behavioural intention in the research related to public transportation. Undoubtedly, passengers would always like and expect public transportation services to be perfectly standardised and streamlined so that they could use the services without any setbacks. They would have certain expectations before using the services and are likely to compare their expectations with their actual experiences. The result of such comparisons will determine their level of service quality and this will lead to their behavioural intentions.

Examining service quality dimensions and their relationship to behavioural intention is important. Many studies (e.g. Perez, Abad, Carrillo, \& Fernandez, 2007; Dabholkar, Shepherd, \& Thorpe, 2000) have shown the relationship between service quality and behavioural purchase intention or behavioural intention. Perez et al. (2007) indicated that there are five dimensions of service quality which comprise tangibility, reliability, receptivity/responsiveness, assurance and empathy. These dimensions are also associated with the individual's behavioural intention to use the service provided. Based on this argument, service quality was also added as a variable to the current study. The factors associated with service quality (i.e., reliability and responsiveness) were considered as antecedents, rather than dimensions or components of the constructs. As Dabholkar et al. (2000) have shown, such an approach offers a greater understanding of the evolving service quality construct.

\subsection{SERVQUAL Model}

According to Lovelock, Vandermerwe, Lewis, and Fernie (2011), most people have difficulties in defining service because its production process is intangible. The service industry differs from the manufacturing or agriculture industry where the latter produces physical goods which can be evaluated based on physical attributes. Services, in contrast, is fundamentally invisible although it may also involve certain percentage 
of physical goods. The production of services does not commonly end with the production of any physical materials.

Service quality is usually measured by a well-known tool called, SERVQUAL which was developed by Parasuraman, Zeithaml and Berry (1985). The tool contains five dimensions namely tangibles, reliability, responsiveness, assurance and empathy. Tangibles refer to the tangible amenities, the furnishings and the employee's appearance. Reliability refers to the ability to accomplish an agreed service consistently, precisely and without fail. Responsiveness refers to the employee's willingness to assist customers and to offer on-time services. Assurance refers to the employees' know-how, their good manners and their capability to encourage trust and confidence. Finally, empathy is a form of tenderness; it is a personalised attention bestowed on the customers by the employees. The SERVQUAL tool has been widely used in various industries and contexts with some adjustments made to the instruments to tailor to the needs of certain contexts. As an example, the E-S-QUAL was developed from the SERVQUAL and used to assess electronic service quality such as Internet banking (Randheer, Al-Motawa, \& Vijay, 2011). When using the SERVQUAL as an instrument to assess service quality, some scholars (e.g. Chang \& Yeh, 2002) emphasised the imperative need to select specific quality attributes that can reflect the service environment being observed. This implies that the SERVQUAL tool can be very much context-dependent. In that respect, the current study adjusted the SERVQUAL tool to tailor suit the transportation industry of Jakarta. This is done to ensure its relevancy to the context of the study so that the questionnaire developed is more meaningful.

Despite its extensive application, the SERVQUAL tool has been criticised based on conceptual and operational grounds. One major objection raised about the tool is the engagement of customers' expectations and perceptions to represent service quality. While perception is definable and measurable because it represents consumers' experiences about a particular service, expectations are subjected to multiple interpretations, as noted in several studies (e.g. Jain \& Gupta, 2004; Dabholkar et al., 2000; Brown, Churchill, \& Peter, 1993). This can cause the tool to have poor reliability. Cronin and Taylor (1992) also raised the issue of the SERVQUAL scale. They asserted that the "expectation" component of the SERVQUAL tool should be discarded and be replaced with the "performance" component solely. They offered empirical evidence drawn from four industries namely banks, pest control, dry cleaning and fast food, to demonstrate this assertion. Eventually, they 
created a new instrument which was termed as SERPERF. Given the criticism noted by prior studies, this study thus considers using the onestage form of service quality measurement namely, SERVPERF.

\subsubsection{Tangibles}

Tangibles, as defined above, are associated with tangible amenities, furnishings and employee's appearance. These have been highlighted as an important attribute that contributes to service quality. In a study conducted by Joewono and Kubota (2007), tangible aspects such as comfortable seats and good security were among the pertinent aspects of service quality. Their respondents claimed to be dissatisfied with the cleanliness of the vehicles and the bus stops. Similarly, Lai and Chen (2011) also detected that users of the Mass Rapid Transit System in Kaohsiung place importance on the physical environment such as conditions at terminals and stops, and vehicle and facility cleanliness. Supporting this, Brady and Cronin Jr. (2001) also discovered that tangibles influence service quality. Based on this, the hypothesis formulated is as follows:

$\mathrm{H}_{1}$ : Tangibles have a positive influence on service quality.

\subsubsection{Reliability}

Reliability refers to the ability to accomplish an agreed service precisely and consistently, without fail. In a study of airline services in Taiwan, Chen (2008) identified reliability to be an important attribute of perceived service performance. Based on a collaborative research by TRL Limited, the Universities of Leeds, Oxford and Westminster, and the University College of London (Paulley, et al., 2006), it was found that the main factor to consider when examining the reliability of public transport services is excessive waiting time. This is because a long wait in a service transaction can be frustrating for the passengers. Thus, it is plausible to assume that a long waiting time for transportation services will disrupt the passengers' daily schedules and activities. An excessively long waiting time for buses in Singapore was observed to drive away the anxious passengers and to make them reluctant to take public transport (Lee, Sun, \& Erath, 2012). In Ghana, it was found that passengers of the Metro Mass Transit (MMT) are dissatisfied with the services of the MMT due to the long journey time (Birago, Mensah, \& 
Sharma, 2017). The passengers traced this problem to the frequent and unneccesary stops of allowing passengers to alight and board the MMT. Redman, Friman, Garling, and Hartig (2013) also found the dimension of reliability to be a key attribute of public transport quality. This dimension can eventually alter the behaviour of private car users to use public transportation. Based on this, the hypothesis formulated is as follows:

$\mathrm{H}_{2}$ : Reliability has a positive influence on service quality.

\subsubsection{Responsiveness}

Responsiveness is a form of employee willingness to assist customers and to offer on-time services. Some studies (Randheer et al., 2011; Prasad \& Shekhar, 2010; Zakaria, Hussin, Batau \& Zakaria, 2010) found the willingness of employees to help customers and their ability to respond to customers as important indicators of the responsiveness attribute. In the context of public transport services, high levels of responsiveness appear to be highly relevant. For instance, providing clear information to passengers in the case of delay or responding to any errors, can instil positive impressions and satisfaction towards the service (Yavas, Bilgin, \& Shemwell, 1997). Responsiveness was also used as a means to reduce the impact of public transport disruptions (Papangelis et al., 2016). Commonly, during service disruptions, passengers who are affected begin to gather as much information as possible from multiple channels. Hence, being responsive by providing real time information just prior to and during the journey, is extremely valuable for the passengers. This can influence pasengers' travel behaviour, cultivate positive attitudes towards the service providers and create positive perceptions of efficiency. Based on this, the hypothesis formulated is as follows:

$\mathrm{H}_{3}$ : Responsiveness has a positive influence on service quality.

\subsubsection{Assurance}

Assurance in the transportation context mainly concerns safety and security during the journey (Prasad \& Shekhar, 2010). In their study looking at New Zealand, Cavana et al. (2007) found assurance to be the most important service quality factor followed by responsiveness and empathy. In Malaysia, majority of the passengers of public transport indicated that they still have doubts over the safety assurance level provided by public transportations (Dahalan, D'Silva, Abdullah, 
Ismail \& Ahmad, 2015). Most of them cited robbery and snatch thieves as the most relevant security aspect. They highlighted that overloading passengers during peak hours will contribute to robbery and sexual harassment on board public transport. In the U.K., Beecroft and Pangbourne (2015) observed that knowledge of the location and routes or confidence in signage while in unfamiliar places, can reduce passenger uncertainty about the journey thereby making them feel more secure. The study also demonstrated that fear of slips or trips in the vehicle is associated with the security confidence and this is more prevalent among the elderly pasengers or the disabled passengers. Based on this, the hypothesis formulated is as follows:

$\mathrm{H}_{4}$ : Assurance has a positive influence on service quality.

\subsubsection{Empathy}

Many studies (Kumar, 2012; Vanniarajan \& Stephen, 2008; Nandan, 2010; Khairul Baharein, \& Kamariah, 2013) have established a link between empathy and service quality. Kumar (2012) incorporated empathy as an important attribute of service quality. He used indicators such as dealing with customers in a caring fashion and understanding customer needs. Likewise, Vanniarajan and Stephen (2008) and Nandan (2010) also identified empathy as an attribute that passengers used to evaluate the service quality of the Indian Railways. Within the Malaysian context, Khairul Baharein and Kamariah (2013) reported that a majority of the passengers interviewed were not happy with the customer service personnel's attitude at the bus hubs. They indicated that customer service providers showed a lack of eye contact and a smiling face when communicating with passengers. Some had also indicated that the personnel seemed to be unfriendly in the late afternoons as compared to the mornings. It is presumed that the long working hours of the employees had led to their fatigue which contributed to their behaviour and attitude towards passengers. Based on this, the hypothesis formulated is as follows:

$\mathrm{H}_{5}$ : Empathy has a positive influence on service quality.

\subsection{Service Quality, Customer Satisfaction and Perceived Value}

Customer satisfaction refers to the customer's cognitive and affective reaction when responding to a certain service engagement $(\mathrm{Hu}$, 
Kandampully, \& Juwaheer, 2009; Wu, Lin, \& Hsu, 2011). Many studies (Carrillat, Jaramillo, \& Mulki, 2007; Islam, Chowdhury, Sarker, \& Ahmed, 2014) have documented a positive relationship between service quality and customer satisfaction. Within the public transportation literature, Islam et al. (2014) found that the operational failures of public transportations such as delay of transportations can create frustations among the passengers and this causes customer dissatisfaction. Afolabi, Hassan and Age (2017) also highlighted that inadequate facilities at bus stops such as insufficient seats and shelters to protect passengers from the sun, rain, dust and other elements that would impact health and safety, also affect the level of passengers' satisfaction with public bus services. Based on this, the hypothesis formulated is as follows:

$\mathrm{H}_{6}$ : Service quality is positively related to customers' satisfaction.

While extensive literature (Caruana, Money, \& Berthon, 2000; Zeithaml, 1988; Park, 2007) have demonstrated the relationship between service quality and customers' satisfaction, it appears that high service quality does not necessarily trigger high satisfaction and satisfaction does not need to be dependent on service quality per se. High service quality leads to good satisfaction level only when customers perceive good values, which are mostly linked to low or competitive prices. These arguments suggest that the relationship and the effect of service quality on customer satisfaction is not direct. In fact, it may be moderated by customers' perceived value (Caruana, Money, \& Berthon, 2000). Zeithaml (1988) defines perceived value as the customers' evaluation of a product or service based on their view of what is received and what is given. It is about how customers/consumers perceive what they could gain and how much costs they need to bear by using a certain product or service. Consumers' perceived costs comprise both economical and non-economical prices such as time, search, psychological costs, price and others. Viewing from the public transportation industry, Park (2007) considers perceived value to mean the exchange between the price of tickets and the services given. Based on this, the hypothesis formulated is as follows:

$\mathrm{H}_{7}$ : Perceived value moderates the relationship between service quality and customer satisfaction.

Previous literature (Chao, Shyr, Chao, \& Tsai, 2012) has established a relationship between perceived value and service quality in which service quality was found to influence perceived value. Chao et al. 
(2012) also found that Gen Y passengers' rated the service quality of high speed rail based on their emotional values towards the services. The passengers in the study mentioned that they liked and enjoyed the high speed rail and they felt relaxed when taking the service. Lo, van Breukelen, Peters and Kok (2013) stated that whilst it is possible to travel by train to European destinations, office workers generally chose to fly because they value time more than cost. They felt that travelling by train would have taken more time. They would only decide to use the train services if it takes lesser time than flying. Based on this, the hypothesis formulated is as follows:

\section{$\mathrm{H}_{8}$ : Service quality has a positive influence on perceived value.}

The role of perceived value, as a predictor of customer satisfaction, has also been highlighted in prior empirical works (Pratminingsih, Rudatin, \& Suhardi, 2013; Hapsari, Clemes, \& Dean, 2015; Parasuraman, Zeithaml, \& Berry, 1988). For example, Pratminingsih et al. (2013) emphasised that there is a positive relationship between perceived value and passenger satisfaction. Hapsari et al. (2015) also found a positive and significant influence of perceived value on customer satisfaction. This approach departs from the traditional perspective which only relates service quality to customer satisfaction (Parasuraman et al., 1988). Accordingly, a passenger will be satisfied with the transportation service delivered if he/she perceives that the service is in line with his/her perceived value. On using the service, a passenger will judge the service based on what he/she values more. In the context of the Indonesian airline, Hapsari et al. (2015) found that passengers have their own goals which will influence their way of interacting or patronising the service. Passengers who travel on business trips may not be able to tolerate delayed flights as this is inconsistent with their perceived values. Hence, they were more likely to develop higher levels of customer dissatisfaction. Based on this, the hypothesis formulated is as follows:

$\mathrm{H}_{9}$ : Perceived value has a positive influence on customer satisfaction.

\subsection{Customer Satisfaction and Behavioural Intention}

Customer satisfaction has been well established to be a significant predictor for behavioural intention in literature. For example, de Ona et al. (2015) found that transit passengers' behavioural intentions in the future are influenced by their level of satisfaction which may vary 
from one to another. Their perceptions about the different characteristics of the service, costs and benefits/gains help to form their level of satisfaction. Birago et al. (2017) illustrated that customers' dissatisfaction about the time schedule and seats capacity are among the reasons for passengers not using the Metro Mass Transit in Africa. Based on this, the hypothesis formulated is as follows:

$\mathrm{H}_{10}$ : Customer satisfaction has a positive influence on behavioural intention.

\subsection{Corporate Image, Service Quality, Customer Satisfaction and Behavioural Intention}

Corporate image is a customer's perception towards a company or organisation that is associated with the customer's memory (Keller, 1993). Previous service marketing research (Andreassen \& Lindestad, 1998) had identified the essential role of corporate image in the company's service evaluation. A good corporate image can make a corporate stand out in the crowd and this allows the company to retain a loyal customer or to gain a new customer's attention (Connor \& Davidson, 1997).

Corporate image is influenced by service quality positively ( $\mathrm{Hu}$ et al., 2009). This is traced to Park, Robertson and Wu (2004) who demonstrated that airline passengers' perceptions of the service quality help to project a good airline image. A passenger's image of the airline company is found to be commonly based on long-term experiences which encompass many service encounters.

There is a general consensus that corporate image affects the future behaviour of consumers, as noted by literature (e.g. Chen \& Tsai, 2007). These studies argue that customers' patronising behaviour towards a particular company depends on the company's corporate image. In a fast food service restaurant setting, Prendergast and Man (2002) revealed that waiting time, store environment and store location help to build the company's corporate image which would affect the customers' future intention. Within the airline industry, Hussain, Nasser and Hussain (2015) identified corporate image to be vital in attracting passengers and for distinguishing a company from other competitors. Their study highlight that the more reputable an airline is, the more trust it can build among its passengers. This consequently leads to future service purchases. Various sources (e.g., Chen \& Tsai, 2007) have 
also shown corporate image to be a predictor for customer satisfaction. Based on this, the hypotheses formulated are as follows:

$\mathrm{H}_{11}$ : Service quality has a positive influence on corporate image.

$\mathrm{H}_{12}$ : Corporate image has a positive influence on behavioural intention.

$\mathrm{H}_{13}$ : Corporate image has a positive influence on customer satisfaction.

\subsection{Age Segmentation}

Age plays an important role in consumer behaviour. It affects the customers' consumption patterns and it has been linked to the essential social and psychographic dimensions (Wagar \& Lindqvist, 2010). Age is a common tool for consumer market segmentation in marketing where it is used to target different groups of customers. Prior studies (Elvik \& Bjornskau, 2005; Rojo, Gonzalo-Orden, Dell'Ollio, \& Ibeas, 2011) suggested that customers' expectations of services may vary across contexts where service is differentiated by customer characteristics. Within the context of public transportation, different ages have different life styles and these differences may significantly influence their needs and expectations for service. As individuals age, their personal mobility becomes increasingly impaired by their changing health and physical limitations and this likewise, affect their expectations of services. This is expected to affect their perceptions and behaviour towards public transportation (Elvik \& Bjornskau, 2005; Rojo et al., 2011). Based on this, the hypothesis formulated is as follows:

$\mathrm{H}_{14}$ : There is a difference in behaviour between the two age groups of customers.

\section{Research Methodology}

Based on the literature review, a conceptual model consisting of ten variables was formulated, as shown in Figure 1. The five dimensions of service quality were adapted from Parasuraman et al. (1985) and the indicators to measure them were adapted from various sources as can be seen in Appendix A.

In this study, data were collected through an online survey. A questionnaire incorporating a five-point Likert-type scale ranging from "One (1) = strongly disagree" to "Five (5) = strongly agree" was used. 


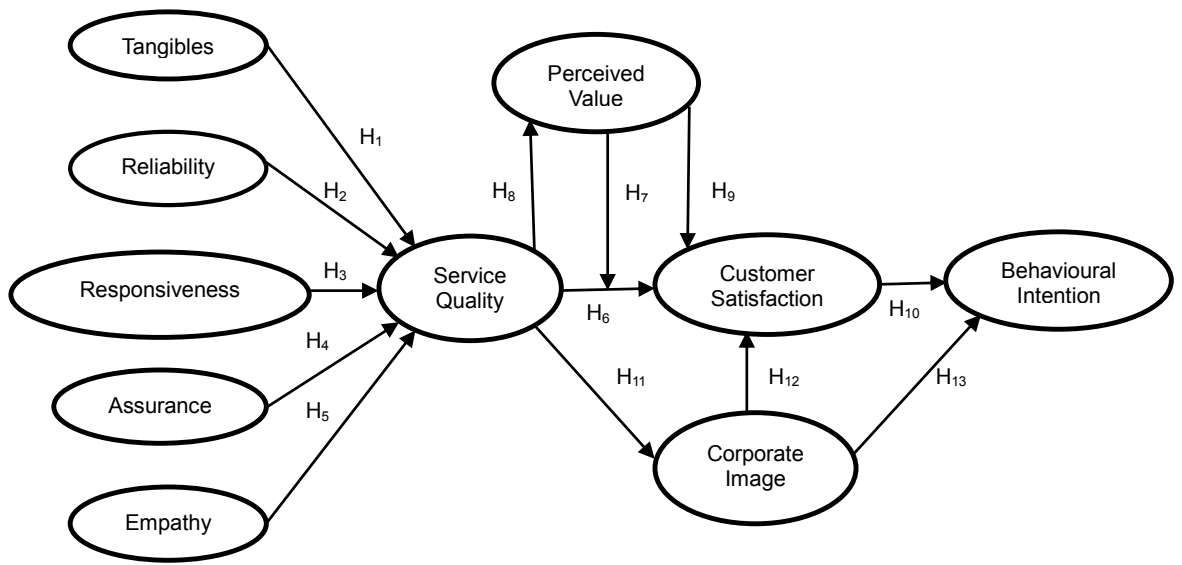

Figure 1: Research Model

A double back to back translation was performed on the questionnaire where it was translated from English to the Indonesian language and then back to the English language. This was performed by two bilingual researchers so as to avoid language related errors. The bilingual researchers are native speakers of Bahasa Indonesia with advanced knowledge of English.

As there was no accessible database of the KA Commuter Line (KRL) Jabodetabek users, non-probability sampling was used in this study. The questionnaire was hosted online and the link was distributed through two Facebook members who were also bloggers and have 7,000 followers cumulatively. The respondents were encouraged to forward the survey link to their followers. The questionnaire was also distributed to the online community of KA Commuter Line (KRL) Jabodetabek. KA Commuter Line (KRL) Jabodetabek has gone through dramatic changes over the past years, with substantial improvements during the past three months (at the time the questionnaire was administered). To ensure that the respondents experience a similar level of services and that they can still recall their experiences in using the railway services, a screening question was used. Only those who had used the service in the past three months (at the time the questionnaire was administered) were included. Through the snowballing technique, 213 valid responses were obtained.

The respondents were then divided into two groups namely, a younger passenger group comprising those below 29 years of age and 
an older passenger group who were 29 years old and above. Twentynine years old was chosen as the cut-off age because it is the median age of the Indonesian population (Central Intelligence Agency, 2014). Independent sample $\mathrm{t}$-test was used to analyse whether there is a difference between the two age groups. Several models of ordinary least squares (OLS) regression were then analysed to evaluate each path in the conceptual model. The regressions were conducted separately for each group as has been used in previous marketing studies (Parahoo et al., 2014; Shamma \& Hassan, 2009). The moderation effect of perceived values was tested by multiplying the variable with service quality (SQ $x$ PV). The value was then added into the regression model (Hayes \& Matthes, 2009).

\section{Analysis and Findings}

\subsection{Descriptive Analysis}

Table 1 depicts the demographic profiles of the respondents. Of the 213 respondents, 53 per cent were females with majority belonging to the younger group. Almost half of the respondents worked in the

Table 1 : Respondent Profile

\begin{tabular}{llrr}
\hline Variables & Categories & Frequency & Percentage \\
\hline Gender & Female & 113 & 53.0 \\
& Male & 100 & 47.0 \\
\hline \multirow{2}{*}{ Age } & Under 29 & 132 & 62.0 \\
& 29 years and above & 81 & 38.0 \\
\hline Occupation & Private Sector Workers & 97 & 45.5 \\
& Civil Servants & 24 & 11.3 \\
& Teachers/Lecturers & 9 & 4.2 \\
& Students & 68 & 3.9 \\
& Entrepreneurs & 3 & 1.4 \\
& Others & 12 & 5.6 \\
\hline Motor Vehicle & Owns a motorcycle & 88 & 41.3 \\
Ownership & Owns a car & 32 & 15.0 \\
& Owns a motorcycle and a car & 57 & 26.8 \\
& Does not own a vehicle & 31 & 16.0 \\
& Others & 2 & 0.94 \\
\hline
\end{tabular}


private sector. Students formed the second largest group of respondents who used the transportation. Based on these figures, it appears that these two groups of respondents were the frequent users of the KA Commuter Line (KRL) Jabodetabek. They used the service to commute to work, school, or university on a daily basis. It is interesting to note that almost all of the respondents own a vehicle mostly, motorcycles. Some respondents even own both a motorcycle and a car. This indicates that railway services can become an alternative for commuting and can reduce the utilisation of private vehicles.

Table 2 depicts the mean and standard deviation of each item and variable tested in this study. The results indicate that the users of the KA Commuter Line (KRL) Jabodetabek railway services generally have a good perception on the quality of services offered by the company. They were also satisfied with the services and they have a favourable behavioural intention towards the service.

\subsection{Reliability and Validity}

All the survey instruments were validated using Cronbach's Alpha (internal consistency) and factor analysis (construct validity). As evident in Table 3, all scales achieved were above 0.6 (0.835 to 0.935), indicating a high level of internal consistency (Malhotra, 2010).

Factor analysis was then conducted to assess the construct validity of each variable. Exploratory factor analysis was utilised to analyse the determinants of service quality. The principle components with Varimax rotation method were chosen (Abdi, 2003). In this study, factor analysis was done in a more confirmatory approach where each factor was analysed separately. This is because the instruments used are well-established. The aim of using factor analysis was to determine whether a hypothesised factor structure is supported by the data. The Kaiser-Meyer-Olkin Measure of Sampling Adequacy and Bartlett's Test of Sphericity were also observed to determine whether factor analysis was suitable to be conducted. Both indicators provide a value of above 0.6 , with a $p$-value $<0.001$, demonstrating the suitability of the factor analysis (Malhotra, 2010). All the items loaded were above 0.5, with a $p$-value $<0.001$ (Hair, Black, Babin, \& Anderson, 2009). These results indicate that the scales used in this study were both reliable and valid. 
Table 2. Descriptive Statistics of the Items

\begin{tabular}{|c|c|c|c|c|c|}
\hline Variables & Indicators & Mean & $\begin{array}{c}\text { Overall } \\
\text { Mean }\end{array}$ & $\begin{array}{l}\text { Standard } \\
\text { Deviation }\end{array}$ & $\begin{array}{c}\text { Overall Std. } \\
\text { Deviation }\end{array}$ \\
\hline Tangibles & $\begin{array}{l}\text { TAN1 } \\
\text { TAN2 } \\
\text { TAN3 } \\
\text { TAN4 } \\
\text { TAN5 } \\
\text { TAN6 }\end{array}$ & $\begin{array}{l}4.5023 \\
4.1596 \\
4.7230 \\
3.9765 \\
4.4742 \\
3.6338\end{array}$ & 4.2449 & $\begin{array}{l}1.04441 \\
1.14219 \\
0.90245 \\
1.22644 \\
1.04860 \\
1.51321 \\
\end{array}$ & 0.86064 \\
\hline Reliability & $\begin{array}{l}\text { REL1 } \\
\text { REL2 } \\
\text { REL3 } \\
\text { REL4 } \\
\text { REL5 }\end{array}$ & $\begin{array}{l}3.6291 \\
3.8545 \\
3.2629 \\
4.2535 \\
4.3099\end{array}$ & 3.8620 & $\begin{array}{l}1.34883 \\
1.35021 \\
1.40631 \\
1.15805 \\
0.98467\end{array}$ & 1.01587 \\
\hline Responsiveness & $\begin{array}{l}\text { RES1 } \\
\text { RES2 } \\
\text { RES3 } \\
\end{array}$ & $\begin{array}{l}4.0329 \\
3.9765 \\
4.3897 \\
\end{array}$ & 4.1330 & $\begin{array}{l}1.18316 \\
1.20315 \\
1.10457\end{array}$ & 1.07357 \\
\hline Assurance & $\begin{array}{l}\text { ASS1 } \\
\text { ASS2 } \\
\text { ASS3 } \\
\text { ASS4 } \\
\text { ASS5 }\end{array}$ & $\begin{array}{l}4.3146 \\
4.2488 \\
4.3991 \\
4.1878 \\
3.8826\end{array}$ & 4.2066 & $\begin{array}{l}1.06825 \\
1.23589 \\
1.04854 \\
1.15434 \\
1.37715\end{array}$ & 0.93069 \\
\hline Empathy & $\begin{array}{l}\text { EMP1 } \\
\text { EMP2 } \\
\text { EMP3 } \\
\text { EMP4 } \\
\text { EMP5 }\end{array}$ & $\begin{array}{l}3.8310 \\
4.0563 \\
4.4930 \\
3.7371 \\
4.1596\end{array}$ & 4.0554 & $\begin{array}{l}1.32094 \\
1.27628 \\
1.20776 \\
1.18417 \\
1.19071\end{array}$ & 0.97561 \\
\hline Service Quality & $\begin{array}{l}\text { SQ1 } \\
\text { SQ2 } \\
\text { SQ3 } \\
\end{array}$ & $\begin{array}{l}4.1784 \\
3.5493 \\
3.6808 \\
\end{array}$ & 3.8028 & $\begin{array}{l}1.06669 \\
1.17106 \\
1.25196 \\
\end{array}$ & 1.02880 \\
\hline Perceived Value & $\begin{array}{l}\text { PV1 } \\
\text { PV2 } \\
\text { PV3 }\end{array}$ & $\begin{array}{l}4.5634 \\
4.4601 \\
4.3756\end{array}$ & 4.4664 & $\begin{array}{l}1.03795 \\
1.15928 \\
1.09878\end{array}$ & 0.97212 \\
\hline Corporate Image & $\begin{array}{l}\text { CI1 } \\
\text { CI2 } \\
\text { CI3 }\end{array}$ & $\begin{array}{l}4.2066 \\
4.6761 \\
4.2113 \\
\end{array}$ & 4.3646 & $\begin{array}{l}1.13875 \\
1.06543 \\
1.09349\end{array}$ & 0.97078 \\
\hline $\begin{array}{l}\text { Customer } \\
\text { Satisfaction }\end{array}$ & $\begin{array}{l}\text { CS1 } \\
\text { CS2 } \\
\text { CS3 }\end{array}$ & $\begin{array}{l}4.8545 \\
4.9296 \\
4.7089\end{array}$ & 4.8310 & $\begin{array}{l}0.97247 \\
0.92640 \\
0.99989\end{array}$ & 0.90920 \\
\hline $\begin{array}{l}\text { Behavioural } \\
\text { Intention }\end{array}$ & $\begin{array}{l}\text { BI1 } \\
\text { BI2 } \\
\text { BI3 } \\
\text { BI4 }\end{array}$ & $\begin{array}{l}4.4366 \\
4.1174 \\
4.9437 \\
4.8685\end{array}$ & 4.8415 & $\begin{array}{l}1.12097 \\
0.95677 \\
1.11025 \\
1.08662\end{array}$ & 0.92868 \\
\hline
\end{tabular}


Table 3: Scale Assessment

\begin{tabular}{|c|c|c|c|c|c|c|c|}
\hline Variables & Indicators & $\begin{array}{l}\text { Factor } \\
\text { Loading }\end{array}$ & $\begin{array}{l}\text { Eigen- } \\
\text { value }\end{array}$ & $\begin{array}{l}\text { Variance } \\
\text { Explained }\end{array}$ & $\begin{array}{c}\text { Kaiser-Meyer- } \\
\text { Olkin Measure } \\
\text { of Sampling } \\
\text { Adequacy }\end{array}$ & $\begin{array}{l}\text { Bartlett's } \\
\text { Test of } \\
\text { Sphericity }\end{array}$ & $\begin{array}{l}\text { Cron- } \\
\text { bach's } \\
\text { Alpha }\end{array}$ \\
\hline Tangibles & $\begin{array}{l}\text { TAN1 } \\
\text { TAN2 } \\
\text { TAN3 } \\
\text { TAN4 } \\
\text { TAN5 } \\
\text { TAN6 }\end{array}$ & $\begin{array}{l}0.779 \\
0.721 \\
0.766 \\
0.804 \\
0.721 \\
0.711\end{array}$ & 3.386 & 56.429 & 0.829 & 0.000 & 0.835 \\
\hline Reliability & $\begin{array}{l}\text { REL1 } \\
\text { REL2 } \\
\text { REL3 } \\
\text { REL4 } \\
\text { REL5 }\end{array}$ & $\begin{array}{l}0.835 \\
0.859 \\
0.841 \\
0.730 \\
0.773\end{array}$ & 3.274 & 65.481 & 0.822 & 0.000 & 0.866 \\
\hline $\begin{array}{l}\text { Responsive- } \\
\text { ness }\end{array}$ & $\begin{array}{l}\text { RES1 } \\
\text { RES2 } \\
\text { RES3 }\end{array}$ & $\begin{array}{l}0.913 \\
0.947 \\
0.906\end{array}$ & 2.552 & 85.054 & 0.733 & 0.000 & 0.912 \\
\hline Assurance & $\begin{array}{l}\text { ASS1 } \\
\text { ASS2 } \\
\text { ASS3 } \\
\text { ASS4 } \\
\text { ASS5 }\end{array}$ & $\begin{array}{l}0.868 \\
0.748 \\
0.865 \\
0.800 \\
0.695\end{array}$ & 3.185 & 63.699 & 0.820 & 0.000 & 0.846 \\
\hline Empathy & $\begin{array}{l}\text { EMP1 } \\
\text { EMP2 } \\
\text { EMP3 } \\
\text { EMP4 } \\
\text { EMP5 }\end{array}$ & $\begin{array}{l}0.733 \\
0.786 \\
0.778 \\
0.785 \\
0.868 \\
\end{array}$ & 3.132 & 62.630 & 0.820 & 0.000 & 0.848 \\
\hline $\begin{array}{l}\text { Service } \\
\text { Quality }\end{array}$ & $\begin{array}{l}\text { SQ1 } \\
\text { SQ2 } \\
\text { SQ3 }\end{array}$ & $\begin{array}{l}0.885 \\
0.926 \\
0.843 \\
\end{array}$ & 2.352 & 78.393 & 0.693 & 0.000 & 0.858 \\
\hline $\begin{array}{l}\text { Perceived } \\
\text { Value }\end{array}$ & $\begin{array}{l}\text { PV1 } \\
\text { PV2 } \\
\text { PV3 }\end{array}$ & $\begin{array}{l}0.872 \\
0.903 \\
0.877\end{array}$ & 2.346 & 78.196 & 0.729 & 0.000 & 0.860 \\
\hline $\begin{array}{l}\text { Corporate } \\
\text { Image }\end{array}$ & $\begin{array}{l}\text { CI1 } \\
\text { CI2 } \\
\text { CI3 } \\
\end{array}$ & $\begin{array}{l}0.885 \\
0.863 \\
0.901 \\
\end{array}$ & 2.339 & 77.979 & 0.727 & 0.000 & 0.858 \\
\hline $\begin{array}{l}\text { Customer } \\
\text { Satisfaction }\end{array}$ & $\begin{array}{l}\text { CS1 } \\
\text { CS2 } \\
\text { CS3 } \\
\end{array}$ & $\begin{array}{l}0.943 \\
0.942 \\
0.938 \\
\end{array}$ & 2.656 & 88.543 & 0.769 & 0.000 & 0.935 \\
\hline $\begin{array}{l}\text { Behavioural } \\
\text { Intention }\end{array}$ & $\begin{array}{l}\mathrm{BI} 1 \\
\mathrm{BI} 2 \\
\mathrm{BI} 3 \\
\mathrm{BI} 4\end{array}$ & $\begin{array}{l}0.839 \\
0.854 \\
0.862 \\
0.918\end{array}$ & 3.022 & 75.547 & 0.797 & 0.000 & 0.890 \\
\hline
\end{tabular}




\subsection{Comparing the Age Groups}

In order to test $\mathrm{H}_{14}$, the data for the younger and older age groups were compared using independent sample t-test. As can be seen in Table 4, there was a difference in the mean for all of the variables examined. All the paths were significant at $p<0.001$ (tangibles, responsiveness, empathy, service quality, perceived value, corporate image, customer satisfaction and behavioural intention) and $p<0.05$ (reliability and assurance). This result indicates that there is a difference in evaluation between the younger and older passengers. This finding validates the findings of previous literature (Wagar \& Lindqvist, 2010; Rojo et al., 2011) on consumer behavioural research.

Table 4. Result of T-Test

\begin{tabular}{|c|c|c|c|c|}
\hline Variables & Age Group & Mean & Std. Deviation & T-value \\
\hline \multirow{2}{*}{ Tangibles } & Young & 4.3813 & 0.82129 & \multirow{2}{*}{$3.008^{* * *}$} \\
\hline & Old & 4.0226 & 0.88182 & \\
\hline \multirow[t]{2}{*}{ Reliability } & Young & 3.9879 & 0.94869 & \multirow[t]{2}{*}{$2.333^{* *}$} \\
\hline & Old & 3.6568 & 1.09189 & \\
\hline \multirow[t]{2}{*}{ Responsiveness } & Young & 4.3081 & 0.995 & \multirow[t]{2}{*}{$3.099^{* * *}$} \\
\hline & Old & 3.8477 & 1.14024 & \\
\hline \multirow[t]{2}{*}{ Assurance } & Young & 4.3318 & 0.89914 & \multirow[t]{2}{*}{$2.539^{* *}$} \\
\hline & Old & 4.0025 & 0.95052 & \\
\hline \multirow[t]{2}{*}{ Empathy } & Young & 4.2273 & 0.90183 & \multirow[t]{2}{*}{$3.361^{* * *}$} \\
\hline & Old & 3.7753 & 1.03072 & \\
\hline \multirow[t]{2}{*}{ Service Quality } & Young & 4.1061 & 0.91849 & \multirow[t]{2}{*}{$5.915^{* * *}$} \\
\hline & Old & 3.3086 & 1.01212 & \\
\hline \multirow{2}{*}{ Perceived Value } & Young & 4.7399 & 0.71849 & \multirow{2}{*}{$5.038^{* * *}$} \\
\hline & Old & 4.0206 & 1.15512 & \\
\hline \multirow{2}{*}{ Corporate Image } & Young & 4.5909 & 0.84668 & \multirow[t]{2}{*}{$4.539^{* * *}$} \\
\hline & Old & 3.9959 & 1.04946 & \\
\hline \multirow[t]{2}{*}{ Customer Satisfaction } & Young & 5.0429 & 0.73146 & \multirow[t]{2}{*}{$4.169^{* * *}$} \\
\hline & Old & 4.4856 & 1.0581 & \\
\hline \multirow[t]{2}{*}{ Behavioural Intention } & Young & 5.0455 & 0.79167 & \multirow[t]{2}{*}{$3.989^{* * *}$} \\
\hline & Old & 4.5093 & 1.03866 & \\
\hline
\end{tabular}

Note: ${ }^{* * *}$ significant at 1 per cent level, ${ }^{* *}$ significant at 5 per cent level, * significant at 10 per cent level. 


\subsection{Assumptions of Regression}

Prior to the hypotheses testing $\left(\mathrm{H}_{1}-\mathrm{H}_{13}\right)$, several assessments of the assumptions of regression were conducted. First, the normality test was conducted by observing the values of skewness and kurtosis so as to ensure a normal data distribution. As indicated in Table 5, the data were distributed normally since the values were in the range of -2 and +2 (George \& Mallery, 2010).

Table 5: Skewness and Kurtosis

\begin{tabular}{lccccc}
\hline & $\mathrm{N}$ & Skewness & Std. Error & Kurtosis & Std. Error \\
\hline Tangibles & 213 & -.276 & .167 & .872 & .332 \\
Reliability & 213 & -.014 & .167 & -.011 & .332 \\
Responsiveness & 213 & -.507 & .167 & .072 & .332 \\
Assurance & 213 & -.313 & .167 & .286 & .332 \\
Empathy & 213 & -.436 & .167 & .382 & .332 \\
Service Quality & 213 & -.332 & .167 & .184 & .332 \\
Perceived Value & 213 & -.895 & .167 & .874 & .332 \\
Corporate Image & 213 & -.674 & .167 & .941 & .332 \\
Customer Satisfaction & 213 & -.823 & .167 & .745 & .332 \\
Behavioural Intentions & 213 & -.898 & .167 & .833 & .332 \\
\hline
\end{tabular}

Next, the Durbin-Watson test was performed to ensure that there was no autocorrelation. As demonstrated in Table 6, all the values for each variable achieved the threshold point (range of 1-3), indicating that they were free from the bias (Field, 2009).

Third, the variables were assessed for the existence of multicollinearity (Table 6). This was done by examining the collinearity diagnostics namely, the Tolerance and Variance Inflation Factor (VIF) values. According to Hair et al. (2009), the acceptable tolerance value is above 0.1 and the acceptable VIF value is 10 or below. All the results indicate an absence of multicollinearity with some values which were not in the acceptable range for service quality and the moderator (service quality $x$ perceived value). However, this was actually expected as service quality was used as one of the input variables to compute the moderating variable. 
Table 6. Durbin-Watson, Tolerance and VIF

\begin{tabular}{|c|c|c|c|c|}
\hline Dependent Variable & $\begin{array}{l}\text { Independent } \\
\text { Variable(s) }\end{array}$ & $\begin{array}{l}\text { Durbin- } \\
\text { Watson }\end{array}$ & Tolerance & VIF \\
\hline \multirow{5}{*}{$\begin{array}{l}\text { Model 1: Service } \\
\text { Quality }\end{array}$} & Tangibles & \multirow[t]{5}{*}{1.861} & 0.337 & 2.966 \\
\hline & Reliability & & 0.203 & 4.937 \\
\hline & Responsiveness & & 0.246 & 4.062 \\
\hline & Assurance & & 0.268 & 3.725 \\
\hline & Empathy & & 0.313 & 3.194 \\
\hline $\begin{array}{l}\text { Model 2: Perceived } \\
\text { Value }\end{array}$ & Service Quality & 1.843 & 1.000 & 1.000 \\
\hline $\begin{array}{l}\text { Model 3: Corporate } \\
\text { Image }\end{array}$ & Service Quality & 1.692 & 1.000 & 1.000 \\
\hline \multirow{4}{*}{$\begin{array}{l}\text { Model 4: Customer } \\
\text { Satisfaction }\end{array}$} & Service Quality & \multirow[t]{4}{*}{1.744} & 0.061 & 16.437 \\
\hline & Perceived Value & & 0.124 & 8.082 \\
\hline & $\begin{array}{l}\text { Service Quality x } \\
\text { Perceived Value }\end{array}$ & & 0.032 & 31.443 \\
\hline & Corporate Image & & 0.329 & 3.039 \\
\hline \multirow{2}{*}{$\begin{array}{l}\text { Model 5: Behavioural } \\
\text { Intention }\end{array}$} & Corporate Image & \multirow[t]{2}{*}{1.724} & 0.440 & 2.272 \\
\hline & Customer Satisfaction & & 0.440 & 2.272 \\
\hline
\end{tabular}

\subsection{Younger Passengers}

Due to the nature of the research model, a series of regression analysis were conducted to examine the relationships between the variables in the study. The results of five regression models are summarised in Table 7. It is interesting to note that none of the service quality predictors tangibles $(\beta=0.019, t=0.132)$, reliability $(\beta=0.086, t=0.531)$, responsiveness $(\beta=-0.014, \mathrm{t}=-0.092)$, assurance $(\beta=0.163, \mathrm{t}=1.051)$, empathy $(\beta=0.241$, $\mathrm{t}=1.592$ ) were found to have significant relationship with service quality. Hence, $\mathrm{H}_{1}, \mathrm{H}_{2}, \mathrm{H}_{3}, \mathrm{H}_{4}, \mathrm{H}_{5}$ are rejected. While previous studies (e.g. Lai \& Chen, 2011; Birago et al., 2017; \& Papangelis et al., 2016) had found service quality to be related with the five antecedents, this study did not find substantial evidence to establish the relationship. Perhaps, the result was due to the different context of the research. Since service is characterised as intangible, younger people in Indonesia may have different perceptions about the factors that may influence the service quality. For instance, in Taiwan, Gen Y passengers were found to enjoy the high speed rail and they felt relaxed when taking the service. This 
Table 7. Regression Analysis for Younger Passengers (under 29 years old)

\begin{tabular}{|c|c|c|c|c|c|}
\hline $\begin{array}{l}\text { Dependent } \\
\text { Variable(s) }\end{array}$ & $\begin{array}{c}\text { Independent } \\
\text { Variable(s) }\end{array}$ & $\mathrm{R}^{2}$ & F-value & $\beta$ & t-value \\
\hline $\begin{array}{l}\text { Model 1: Service } \\
\text { Quality }\end{array}$ & $\begin{array}{l}\text { Tangibles } \\
\text { Reliability } \\
\text { Responsiveness } \\
\text { Assurance } \\
\text { Empathy }\end{array}$ & 0.177 & $6.643^{* * *}$ & $\begin{array}{l}0.019 \\
0.086 \\
0.014 \\
0.163 \\
0.241\end{array}$ & $\begin{array}{l}0.132 \\
0.531 \\
0.092 \\
1.051 \\
1.592\end{array}$ \\
\hline $\begin{array}{l}\text { Model 2: Perceived } \\
\text { Value }\end{array}$ & Service Quality & 0.415 & $93.841^{* * *}$ & 0.647 & $9.687^{* * *}$ \\
\hline $\begin{array}{l}\text { Model 3: Corporate } \\
\text { Image }\end{array}$ & Service Quality & 0.451 & $108.586^{* * *}$ & 0.675 & $10.420^{* * *}$ \\
\hline $\begin{array}{l}\text { Model 4: Customer } \\
\text { Satisfaction }\end{array}$ & $\begin{array}{l}\text { Service Quality } \\
\text { Perceived Value } \\
\text { Service Quality x } \\
\text { Perceived Value } \\
\text { Corporate Image }\end{array}$ & 0.557 & $42.177^{* * *}$ & $\begin{array}{l}0.133 \\
0.435 \\
-0.08 \\
\\
0.553\end{array}$ & $\begin{array}{l}0.460 \\
2.087^{* *} \\
-0.183 \\
6.218^{* * *}\end{array}$ \\
\hline $\begin{array}{l}\text { Model 5: Behavioural } \\
\text { Intention }\end{array}$ & $\begin{array}{l}\text { Corporate Image } \\
\text { Customer } \\
\text { Satisfaction }\end{array}$ & 0.537 & $77.084^{* * *}$ & $\begin{array}{l}0.356 \\
0.442\end{array}$ & $\begin{array}{l}4.260^{* * *} \\
5.288^{* * *}\end{array}$ \\
\hline
\end{tabular}

Note: ${ }^{* *} p<0.001,{ }^{* *} p<0.05,{ }^{*} p<0.01$.

factor inadvertently, also affected their perception on service quality (Chao et al., 2012).

As indicated by models 2 and 3 (see Table 7), service quality is significantly related to perceived value $\left(\beta=0.647, \mathrm{t}=9.687^{* * *}\right)$ and corporate image $\left(\beta=0.675, \mathrm{t}=10.420^{* * *}\right)$. Therefore, $\mathrm{H}_{6}$ and $\mathrm{H}_{11}$ are supported. This result is consistent with previous research (Chao et al., 2012; Park et al., 2004). The findings demonstrate that younger passengers will have higher perceived values and they associate the company with good corporate image if they perceived the service quality to be high.

As highlighted by model 4 (Table 7$)$, only perceived value $(\beta=0.435$, $\left.\mathrm{t}=2.087^{* * *}\right)$ and corporate image $\left(\beta=0.553, \mathrm{t}=6.218^{* * *}\right)$ had influenced customer satisfaction. Hence $\mathrm{H}_{9}$ and $\mathrm{H}_{13}$ are accepted. This finding reaffirms previous research (Hapsari et al., 2015; Chen \& Tsai, 2007). The result, however, does not endorse the relationship between service quality and customer satisfaction. It departs from the traditional perspective which associates service quality with customer satisfaction 
(Parasuraman et al., 1988). The inconsistent results indicate that younger passengers will only be satisfied if the services delivered are compatible with their own values and goals. This study also highlights a significant relationship between corporate image with behavioural intention $\left(\beta=0.356, t=4.260^{* * *}\right)$ and customer satisfaction with behavioural intention $\left(\beta=0.442, t=5.288^{* * *}\right)$. The results were expected and similar outcomes have been documented in various consumer behavioural research (e.g. Birago et al., 2017; Hussain et al., 2015). The findings indicate that customer satisfaction and corporate image are important for inducing a positive behavioural intention among younger passengers.

\subsection{Older Passengers}

This study finds that assurance $\left(\beta=0.463, t=2.731^{* *}\right)$ is a determinant for service quality among older passengers hence $\mathrm{H}_{4}$ is supported. This finding demonstrates that older passengers perceive safety and security as important factors which will determine their service quality level. The results could posisbly be due to the fact that as people age they also become more concerned about the security levels when using public transportations (Beecroft \& Pangbourne, 2015). This study illustrates that tangibles $(\beta=0.158, \mathrm{t}=1.135)$, reliability $(\beta=0.03, \mathrm{t}=0.132)$, responsiveness $(\beta=-0.124, \mathrm{t}=-0.681)$ and empathy $(\beta=0.187, \mathrm{t}=1.274)$ were not significantly related to service quality. Therefore, $\mathrm{H}_{1}, \mathrm{H}_{2}, \mathrm{H}_{3}$ and $\mathrm{H}_{5}$ are rejected.

This study highlights that service quality influences both the perceived value $\left(\beta=0.616, t=6.947^{* * *}\right)$ and corporate image $(\beta=0.720$, $\left.t=9.232^{* * *}\right)$ in the context of older passengers, similar to the younger passengers' finding. Therefore, $\mathrm{H}_{8}$ and $\mathrm{H}_{11}$ are supported. This finding is consistent with prior empirical works (Chao et al., 2012; Park et al., 2004). As indicated in Table 8 (model 4), service quality $(\beta=0.548$, $\left.\mathrm{t}=1.876^{* * *}\right)$ and corporate image $\left(\beta=0.526, \mathrm{t}=3.934^{\star * *}\right)$ affect customer satisfaction while perceived value $(\beta=0.134, t=0.578)$ does not play any significant role in predicting customer satisfaction. Hence, $\mathrm{H}_{6}$ and $\mathrm{H}_{13}$ are supported while $\mathrm{H}_{9}$ is rejected. This result however, differs from the younger passengers' outcome. This finding indicates that perceived value varies with the age of passengers. As indicated by model 5 in Table 8 , corporate image $\left(\beta=0.279, \mathrm{t}=3.142^{* * *}\right)$ and customer satisfaction $\left(\beta=0.628, t=7.012^{* * *}\right)$ influence behavioural intention. These results are consistent with previous research (Chen \& Tsai, 2007; Prendergast \& Man, 2002; de Ona et al., 2015). 
Table 8: Older Passenger (Passengers Twenty-Nine (29) Years and Older)

\begin{tabular}{|c|c|c|c|c|c|}
\hline $\begin{array}{l}\text { Dependent } \\
\text { Variable(s) }\end{array}$ & $\begin{array}{l}\text { Independent } \\
\text { Variable(s) }\end{array}$ & $\mathrm{R}^{2}$ & F-value & $\beta$ & t-value \\
\hline $\begin{array}{l}\text { Model 1: Service } \\
\text { Quality }\end{array}$ & $\begin{array}{l}\text { Tangibles } \\
\text { Reliability } \\
\text { Responsiveness } \\
\text { Assurance } \\
\text { Empathy }\end{array}$ & 0.406 & $11.948 * * *$ & $\begin{array}{l}0.158 \\
0.03 \\
0.124 \\
0.463 \\
0.187\end{array}$ & $\begin{array}{l}1.135 \\
0.132 \\
0.681 \\
2.731^{* *} \\
1.274\end{array}$ \\
\hline $\begin{array}{l}\text { Model 2: Perceived } \\
\text { Value }\end{array}$ & Service Quality & 0.371 & $48.261^{* * *}$ & 0.616 & $6.947^{* * *}$ \\
\hline $\begin{array}{l}\text { Model 3: Corporate } \\
\text { Image }\end{array}$ & Service Quality & 0.513 & $85.224^{* * *}$ & 0.720 & $9.232^{* * *}$ \\
\hline $\begin{array}{l}\text { Model 4: Customer } \\
\text { Satisfaction }\end{array}$ & $\begin{array}{l}\text { Service Quality } \\
\text { Perceived Value } \\
\text { Service Quality x } \\
\text { Perceived Value } \\
\text { Corporate Image }\end{array}$ & 0.629 & $34.918 * * *$ & $\begin{array}{l}0.548 \\
0.134 \\
0.646 \\
0.526\end{array}$ & $\begin{array}{l}1.876^{*} \\
0.578 \\
1.604 \\
3.934^{* * *}\end{array}$ \\
\hline $\begin{array}{l}\text { Model 5: Behavioural } \\
\text { Intention }\end{array}$ & $\begin{array}{l}\text { Corporate Image } \\
\text { Customer Satisfacti }\end{array}$ & 0.720 & $103.632^{* * *}$ & $\begin{array}{l}0.279 \\
0.628\end{array}$ & $\begin{array}{l}3.142^{* * *} \\
7.012^{* * *}\end{array}$ \\
\hline
\end{tabular}

Note: ${ }^{* *} p<0.001,{ }^{* *} p<0.05,{ }^{*} p<0.01$.

\section{Discussion, Conclusion and Implication}

The findings of this study indicate that age plays an important role in customers' consumption patterns of the railway services in Indonesia. It specifically reveals that perceived value emerged as a significant predictor for customer satisfaction which in turn, influences behavioural intention for the younger passenger group. Meanwhile, for the older passenger group, perceived value does not play a role. Instead, customer satisfaction is associated with service quality. These results imply that the younger passenger group are more value conscious. The level of service quality does not significantly influence their satisfaction with the KA Commuter Line (KRL) Jabodetabek services. It is plausible to argue that the younger passengers are predominantly students who also belonged to the low-income segment. They relied on the financial support of their parents or guardians hence, they tend to focus their attention on meeting their needs of transportation within their limited amount of money rather than the quality of the services (Vargo \& Lusch, 
2008). These results are different from previous findings (Parahoo et al., 2014) which showed that service quality had been traditionally viewed as the key predictor of customer satisfaction. For the older passenger group, customer satisfaction was influenced by the level of service quality and not by their perceived values. This means that the older group were more concerned about the quality of the services, especially assurance, rather than the value they can get for their money. It is acceptable to assume that the price sensitivity decreases as age increases because the older passenger group is assumed to have more security in their jobs and financial aspects when compared to the younger passenger group. Consequently, the older group tends to focus on the service quality and in particular, assurance, from which they can instil their trust and confidence toward the service. This study however, found that both groups consider corporate image and customer satisfaction as predictors to behavioural intention.

The findings of this study provide implications to both theory and practice. The outcome of this study contributes to the field of public transportation and consumer behaviour. It extends on prior works by adopting age segmentation as a means to predict the behavioural intention of public transport utilisation. In this study, service quality was treated as an individual dimension analysis instead of as an aggregate contruct. This approach is expected to produce a more detailed value for service quality improvement (Sachdev \& Verma, 2004). The results of this study also emphasise the importance of exploring the service quality dimensions that are relevant to the passengers of railway services in Indonesia. In particular, the railway services was accentuated due to the need to understand which service quality dimension contribute to perceived value, corporate image and customer satisfaction. This was achieved by utilising a direct or separate service quality analysis. This is more appropriate than using a single generic scale across the different sectors.

In terms of contribution to practices, the results also stresses on the need for the Indonesian Railway Company to consider adopting age segmentations when designing marketing strategies. In order to maintain and increase the younger passengers' (under 29 years old) intention to use the KA Commuter Line (KRL) Jabodetabek services, the management of the Indonesian Railway Company should perform their utmost commitment by enhancing the monetary values of their services. The company can consider setting special rates for the younger segment such as the youths or students who are found to be more price sensitive 
when compared to the older passengers. On the other hand, a different strategy should be undertaken by the Indonesian Railway Company to maintain or increase the older passengers' (29 years old and older) intention to use the KA Commuter Line (KRL) services ) by providing more assurance to them through increasing passenger safety, trust and confidence toward the railway services. Nothwithstanding this, it is also important for the company to build a good corporate image. An effective marketing communication demonstrating the breakthrough improvements or other revolutionary changes need to be conveyed to the public so as to build a good corporate image.

This study has several limitations. Firstly, in the context of the younger passengers, service quality has an influence on perceived value and corporate image even though none of its determinants has a significant influence towards the service quality. Therefore, future researchers should consider using a qualitative or exploratory study to obtain the service quality dimensions that are more relevant to the younger group of passengers. This can provide a deeper analysis on the service quality dimensions. It is further suggested that future researchers conduct a direct analysis of each service quality dimension towards perceived value, corporate image and customer satisfaction, separately. Doing so may generate different results such as showing which service quality dimension needs more focus. This input can be used to further contribute to the examination of public transportation and its service quality. Secondly, the generalisability of this study is confined to the context of Jakarta only due to the small sample size. For that reason, future research should attempt to gather more respondents with a more equal distribution between age segments. Thirdly, the authors did not use SEM because of the insufficient number of respondents to be analysed within a relative short research time frame. This instrument may generate more accurate results as it provides a more comprehensive analysis. Thus it is recommended that furture research take this into consideration. Finally, this study only used age segmentation. Other segmentations such as gender segmentation or income segmentation should be duly considered for future studies.

\section{References}

Abdi, H. (2003). Factor rotations in factor analyses. In M.S. Lewis-Beck, A. Bryman, \& T.F. Liao (Eds.), The Sage encyclopedia of social science research methods (pp. 792-795). Thousand Oaks, CA: Sage Publications. 
Afolabi, O.J., Hassan, A.M., \& Age, L.O. (2017). Behavioral pattern of commercial public transport passengers in Lagos metropolis. Journal of Sustainable Development of Transport and Logistics, 2(1), 40-50. http://dx.doi. org/10.14254/jsdtl.2017.2-1.4

Andreassen, T.W., \& Lindestad, B. (1998). Customer loyalty and complex services: The impact of corporate image, on quality, customer satisfaction and loyalty for customers with varying degrees of service expertise. International Journal of Service Industry Management, 9(1), 7-23. http:// dx.doi.org/10.1108/09564239810199923

Barabino, B., Deiana, E., \& Tilocca, P. (2012). Measuring service quality in urban bus transport: A modified SERVQUAL approach. International Journal of Quality and Service Sciences, 4(3), 238-252. http://dx.doi. org/10.1108/17566691211269567

Beecroft, M., \& Pangbourne, K. (2015). Personal security in travel by public transport: The role of traveller information and associated technologies. IET Intelligent Transport Systems, 9(2), 167-174. http://dx.doi.org/10.1049/ iet-its.2013.0166

Birago, D., Mensah, S.O., \& Sharma, S. (2017). Level of service delivery of public transport and mode choice in Accra, Ghana. Transportation Research Part F: Traffic Psychology and Behaviour, 46(Part B), 284-300. http://dx.doi. org/10.1016/j.trf.2016.09.033

Brady, M.K., \& Cronin Jr, J.J. (2001). Some new thoughts on conceptualizing perceived service quality: A hierarchical approach. Journal of Marketing, 65(3), 34-49.

Brons, M., Givoni, M., \& Rietveld, P. (2009). Access to railway stations and its potential in increasing rail use. Transportation Research Part A, 43(2), 136149. https:// doi.org/10.1016/j.tra.2008.08.002

Brown, T.J., Churchill, G.A., \& Peter, J.P. (1993). Improving the measurement of service quality. Journal of Retailing, 69(1), 127-139. http://dx.doi. org/10.1016/S0022-4359(05)80006-5

Carrillat, F.A., Jaramillo, F., \& Mulki, J.P. (2007). The validity of the SERVQUAL and SERVPERF scales: A meta-analytic view of 17 years of research across five continents. International Journal of Service Industry, 18(5), 472-490. http://dx.doi.org/10.1108/09564230710826250

Caruana, A., Money, A., \& Berthon, P. (2000). Service quality and satisfaction: The moderating role of value. European Journal of Marketing, 34(11/12), 1338-1353. http://dx.doi.org/10.1108/03090560010764432

Cavana, R.V., Corbett, L.M., \& Lo, Y.L. (2007). Developing zones of tolerance for managing passenger rail service quality. International Journal of Quality and Reliability Management, 24(1), 7-31. http://dx.doi. org/10.1108/02656710710720303

Central Intelligence Agency. (2014). The world factbook - Indonesian median age. Retrieved from https://www.cia.gov/library/publications/the-worldfactbook/ fields2177.html 
Chang, Y.H., \& Yeh, C.H. (2002). A survey analysis of service quality for domestic airlines. European Journal of Operational Research, 139(1), 166-177. http:/ / dx.doi.org/10.1016/S0377-2217(01)00148-5

Chao, C.W., Shyr, O.F., Chao, C.H., \& Tsai, L. (2012). What drives collegeage generation $\mathrm{Y}^{\prime}$ s perceived value on high-speed rail. African Journal of Business Management, 6(43), 10786-10790. http://dx.doi.org/10.5897/ AJBM11.2433

Chen, C. (2008). Investigating structural relationships between service quality, perceived value, satisfaction, and behavioral intentions for air passengers: Evidence from Taiwan. Transportation Research Part A, 42(4), 709-717. http/ / dx.doi.org/10.1016/j.tra.2008.01.007

Chen, C.F., \& Tsai, D. (2007). How destination image and evaluative factors affect behavioral intentions? Tourism Management, 28(4), 1115-1122. http:/ / dx.doi.org/10.1016/j.tourman.2006.07.007

Chou, J.S., Kim, C., Kuo, Y.C., \& Ou, N. (2011). Deploying effective service strategy in the operations stage of high-speed rail. Transportation Research Part E: Logistics and Transportation Review, 47(4), 507-519. http://dx.doi. org/10.1016/j.tre.2010.12.004

Connor, D., \& Davidson, J. (1997). Marketing your consulting and professional services. New York, NY: John Wiley and Sons.

Cronin, J.J., \& Taylor, S.A. (1992). Measuring service quality: A reexamination and extension. Journal of Marketing, 56(3), 55-68. http://dx.doi.org/ $10.2307 / 1252296$

Dabholkar, P.A., Shepherd, C.D., \& Thorpe, D.I. (2000). A comprehensive framework for service quality: an investigation of critical conceptual and measurement issues through a longitudinal study. Journal of Retailing, 76(2), 139-173. http://dx.doi.org/10.1016/S0022-4359(00)00029-4

Dahalan, D., D'Silva, J.L., Abdullah, H., Ahmad, N., \& Ismail, I. (2014). Level of prejudiced among youth in Klang Valley, Malaysia towards public transport. Life Science Journal, 11(6), 365-373.

De Ona, J., De Ona, R., Eboli, L., \& Mazzulla, G. (2015). Heterogeneity in perceptions of service quality among groups of railway passengers. International Journal of Sustainable Transportation, 9(8), 612-626. http:// dx.doi.org/10.1080/15568318.2013.849318

Eboli, L., \& Mazzulla, G. (2012). Structural equation modelling for analysing passengers' perceptions about railway services. Procedia - Social and Behavioural Science, 54(October), 96-106. http://dx.doi.org/10.1016/j. sbspro.2012.09.729

Elida, T., \& Mukodim, D. (2015). Quality of service on public mass transit in Jakarta. Paper presented at the 3rd Uzbekistan-Indonesia International Joint Conference on Economic Development and Nation Character Building to Meet the Global Economic Challenges, Indonesia. Retrieved from http:/ / repository.gunadarma.ac.id/809/ 
Elvik, R., \& Bjornskau, T. (2005). How accurately does the public perceive differences in transport risks? An exploratory analysis of scales representing perceived risk. Accident Analysis and Prevention, 37(6), 1005-1011. http://dx.doi.org/ 10.1016/j.aap.2005.05.003

Field, A.P. (2009). Discovering statistics using SPSS (3rd. edition). London: Sage Publications.

Fishbein, M., \& Ajzen, I. (1975). Belief, attitude, intention, and behavior: An introduction to theory and research. Reading, MA: Addison-Wesley.

Gaduh, A., Gracner, T., \& Rothenberg, A.D. (2017). Improving mobility in developing country cities: Evaluating bus rapid transit and other policies in Jakarta. Retrieved from https://4ed04206-a-62cb3a1a-s-sites.googlegroups.com/ site/alexrothenberg/research/BRT_Jakarta_JMP.pdf?

Geetika, G., \& Shefali, N. (2010). Determinants of customers satisfaction on service quality: A study of railway platforms in India. Journal of Public Transportation, 13(1), 97-113. http://dx.doi.org/10.5038/2375-0901.13.1.6

George, D., \& Mallery, M. (2010). SPSS for windows step by step: A simple guide and reference, 17.0 update (10th edition). Boston, MA: Pearson.

Hapsari, R., Clemes, M.D., \& Dean, D. (2015). The role of customer engagement in enhancing passenger loyalty in Indonesian Airline industry: Relationship marketing approach. Asia Pacific Management and Business Application, 3(3), 135-144.

Harmadi, S.H.B., Yudisthira, M.H., \& Koesrindartono, D.P. (2015). How does congestion matter for Jakarta's citizens? Journal of Indonesian Economy and Business, 30(3), 220-238.

Hair, J.F., Black, W.C., Babin, B.J., \& Anderson, R.E. (2009). Multivariate data analysis. Upper Saddle River, NJ: Prentice Hall.

Hayes, A.F., \& Matthes, J. (2009). Computational procedures for probing interactions in OLS and logistic regression: SPSS and SAS implementations. Behavior Research Methods, 41(3), 924-936. http://dx.doi.org/10.3758/ BRM.41.3.924

Hsiao, C.H., \& Yang, C. (2010). Predicting the travel intention to take high speed rail among college students. Transportation Research Part F: Traffic Psychology and Behavior, 13(4), 277-287. http://dx.doi.org/10.1016/j.trf. 2010.04 .011

Hu, H.H.S., Kandampully, J., \& Juwaheer, T.D. (2009). Relationships and impacts of service quality, perceived value, customer satisfaction, and image: An empirical study. The Service Industries Journal, 29(2), 111-125. http://dx.doi.org/ 10.1080/02642060802292932

Hussain, R., Al Nasser, A., \& Hussain, Y.K. (2015). Service quality and customer satisfaction of a UAE-based airline: An empirical investigation. Journal of Air Transport Management, 42(January), 167-175. http://dx.doi. org/10.1016/j.jairtraman.2014.10.001

Irfan, S.M., Kee, D.M.H., \& Shahbaz, S. (2012). Service quality and rail transport in Pakistan: A passenger perspective. World Applied Sciences Journal, 18(3), 361-369. http://dx.doi.org/10.5829/idosi.wasj.2012.18.03.3044 
Islam, R., Chowdhury, M.S., Sarker, M.S., \& Ahmed, S. (2014). Measuring customer's satisfaction on bus transportation. American Journal of Economics and Business Administration, 6(1), 34-41. http://dx.doi.org/10.3844/ajebasp.2014.34.41

Jain, S.K., \& Gupta, G. (2004). Measuring service quality: SERVQUAL vs. SERVPERF scales. Vikalpa, 29(2), 25-38.

Jannah, K.M. (2014, October 24). 30\% pengguna angkot beralih ke motor. Retrieved from http:/ / economy.okezone.com/read/2014/10/24/320/1056510/pem prov-dki-30-pengguna-angkot-beralih-ke-motor

Jen, W., Tu, R., \& Lu, T. (2010). Managing passenger behavioral intention: An integrated framework for service quality, satisfaction, perceived value, and switching barriers. Transportation, 38(2), 321-342. http://dx.doi.org/ 10.1007/s11116-010-9306-9

Joewono, T., \& Kubota, H. (2007). User satisfaction with paratransit in competition with motorization in Indonesia: Anticipation of future implications. Transportation, 34(3), 337-354.

Khafian, N. (2013). The efforts of handling transportation problems in DKI Jakarta through sustainable transportation policy. Jurnal Ilmu Administrasi dan Organisasi, 20(3), 179-185.

Khairul Baharein, M.N, Kamariah, D. (2013). Towards low carbon society: Exploring users' perceptions on the service quality level performance of public transport staff in the Klang Valley. International Journal of Management and Sustainability 2(8), 138-149.

Keller, K.L. (1993). Conceptualizing, measuring, and managing consumer-based brand equity. Journal of Marketing, 57(1), 1-22. http:/ / dx.doi.org/10.2307/ 1252054

Kumar, K.S. (2012). Expectations and perceptions of passengers on service quality with reference to public transport undertakings. IUP Journal of Operations Management, 11(3), 67-81.

Lai, W., \& Chen, C.F. (2011). Behavioral intentions of public transit passengers: The roles of service quality, perceived value, satisfaction and involvement. Transport Policy, 18(2), 318-325. http://dx.doi.org/10.1016/j.tranpol. 2010.09.003

Lee, D.H., Sun, L., \& Erath, A. (2012, April). Study of bus service reliability in Singapore using fare card data. Paper presented at 12th Asia-Pacific Intelligent Transpotation Forum, Singapore.

Liu, C.H., \& Liao, S.K. (2010). An empirical study of factors affecting customer loyalty: Taiwan high-speed rail service industry as an example. International Journal of Services Operations and Informatics, 5(2), 130-157. http:/ / dx.doi.org/ 10.1504/IJSOI.2010.031114

Lo, S.H., van Breukelen, G.J., Peters, G.J.Y., \& Kok, G. (2013). Proenvironmental travel behavior among office workers: A qualitative study of individual and organizational determinants. Transportation Research Part A: Policy and Practice, 56, 11-22. http:/ /dx.doi.org/10.1016/j.tra.2013.09.002 
Lovelock, C.H., Vandermerwe, S., Lewis, B., \& Fernie, S. (2011). Services marketing (Working Paper, Edinburgh Business School). Edinburgh: Heriot-Watt University.

Malhotra, N.K. (2010). Marketing research: An applied orientation. New York, NY: Prentice Hall.

Nandan, S. (2010). Determinants of customer satisfaction on service quality: A study of railway platforms in India. Journal of Public Transportation, 13(1), 97-113.

Papangelis, K., Velaga, N.R., Ashmore, F., Sripada, S., Nelson, J.D., \& Beecroft, M. (2016). Exploring the rural passenger experience, information needs and decision making during public transport disruption. Research in Transportation Business \& Management, 18(March), 57-69. http://dx.doi. org/10.1016/j.rtbm.2016.01.002

Parahoo, S., Harvey, H., \& Radi, G. (2014). Changing consumer behavior paradigms: Does passenger age impact factors influencing MRT usage? Corporate Reputation Review, 17(1), 64-77. http://dx.doi.org/10.1057/crr.2013.25

Parasuraman, A., Zeithaml, V.A., \& Berry, L.L. (1985). A conceptual model of service quality and its implications for future research. Journal of Marketing 49(4), 41-50. http://dx.doi.org/10.2307/1251430

Parasuraman, A., Zeithaml, V.A., \& Berry, L.L. (1988). SERVQUAL: A multipleitem scale for measuring consumer perceptions of service quality. Journal of Retailing, 64(1), 12-40.

Park, J.W. (2007). Passenger perceptions of service quality: Korean and Australian case studies. Journal of Air Transport Management, 13(4), 238-242. http://dx.doi.org/10.1016/j.jairtraman.2007.04.002

Park, J.W., Robertson, R., \& Wu, C.L. (2004). The effect of airline service quality on passengers' behavioral intention: A Korean case study. Journal of Air Transport Management, 10(6), 435-439. http://dx.doi.org/10.1016/j. jairtraman.2004.06.001

Paulley, N., Balcombe, R., Mackett, R., Titheridge, H., Preston, J., Wardman, M., ... \& White, P. (2006). The demand for public transport: The effects of fares, quality of service, income and car ownership. Transport Policy, 13(4), 295-306. http://dx.doi.org/10.1016/j.tranpol.2005.12.004

Perez, M.S., Abad, J.C.G., Carrillo, G.M.M., \& Fernandez, R.S. (2007). Effects of service quality dimensions on behavioral purchase intentions: A study in public-sector transport. Managing Service Quality, 17(2), 134-151. http:// dx.doi.org/ 10.1108/09604520710735164

Prasad, M.D., \& Shekhar, B.R. (2010). Impact of service quality management (SQM) practices on Indian railways: A study of South Central Railways. International Journal of Business and Management, 5(9), 139-146. http:// dx.doi.org/ 10.5539/ijbm.v5n9p139

Pratminingsih, S.A., Rudatin, C.L., \& Suhardi, A.R. (2013). Retaining passengers loyalty in Indonesia railway service. Paper presented at the 4th International Conference on Business and Economic Research, Canada. 
Prendergast, G., \& Man, H.W. (2002). The influence of store image on store loyalty in Hong Kong's quick service restaurant industry. Journal of Foodservice Business Research, 5(1), 45-59. http://dx.doi.org/10.1300/ J369v05n01_03

Rahaman, K.R., \& Rahaman, A. (2009). Service quality attributes affecting the satisfaction of railway passengers of selective route in southwestern part of Bangladesh. Theoretical and Empirical Researches in Urban Management, 3(12), 115-125.

Ramadhan, A. (2015, January 9). Jumlah motor dan mobil di Jakarta tumbuh 12 persen tiap tahun. Retrieved from http://www.antaranews.com/berita/ 473169/jumlah-motor-dan-mobil-di-jakarta-tumbuh-12-persen-tiap-tahun

Randheer, K., Al-Motawa, A.A., \& Vijay, P. (2011). Measuring commuters' perception on service quality using SERVQUAL in public transportation. International Journal of Marketing Studies, 3(1), 21-34. http://dx.doi. org/10.5539/ijms.v3n1p21

Redman, L., Friman, M., Garling, T., \& Hartig, T. (2013). Quality attributes of public transport that attract car users: A research review. Transport Policy, 25(January), 119-127. http:/ / dx.doi.org/10.1016/j.tranpol.2012.11.005

Rojo A.M., Gonzalo-Orden, H., Dell'Ollio, L. \& Ibeas P.A. (2011). Modeling gender perception of quality in interurban bus services. Transport, 164(1), 43-53. http:/ / dx.doi.org/10.1680/tran.9.00031

Sachdev, S.B., \& Verma, H.V. (2004). Relative importance of service quality dimensions: A multisectoral study. Journal of Services Research, 4(1), 93-116.

Shamma, H.M., \& Hassan, S.S. (2009). Customer and non-customer perspectives for examining corporate reputation. Journal of Product $\mathcal{E}$ Brand Management, 18(5), 326-337. http://dx.doi.org/10.1108/10610420910981800

Vanniarajan, T., \& Stephen, A. (2008). Railqual and passenger satisfaction: An empirical study in Southern railways. Asia Pacific Business Review, 4(1), 64-75.

Vargo, S.L., \& Lusch, R.F. (2008). Service-dominant logic: Continuing the evaluation. Journal of Public Administration Review, 40(3), 240-246.

Wagar, K., \& Lindqvist, L. (2010). The role of the customer contact person's age in service encounters. Journal of Services Marketing, 24(7), 509-517. http:/ / dx.doi.org/10.1108/08876041011081069

Wardhani, D.A., \& Budiari, I. (2015, February 5). Jakarta has 'worst traffic in the world'. The Jakarta Post. Retrieved from http://www.thejakartapost.com/ news/2015/02/05/jakarta-has-worst-traffic-world.html

Wu, J.H., Lin, Y, \& Hsu, F. (2011). An empirical analysis of synthesizing the effects of service quality, perceived value, corporate image, and customer satisfaction on behavioral intention in the transport industry: A case of Taiwan high-speed rail. Innovative Marketing, 7(3), 83-99. http://dx.doi. org/ 10.1080/1528008X.2013.802581

Yavas, U., Bilgin, Z., \& Shemwell, D. (1997). Service quality in the banking sector in an emerging economy: A consumer survey. International 
Journal of Bank Marketing, 15(6), 217-223. http://dx.doi.org/10.1108/ 02652329710184442

Zakaria, Z., Hussin, Z.H., Batau, M.F.A., \& Zakaria, Z. (2010). Service quality of Malaysian public transports: A case study in Malaysia / La qualité de service de transports publics Malaisiens: Une etude de cas en Malaisie. Cross-Cultural Communication, 6(2), 84-92.

Zeithaml, V.A. (1988). Consumer perceptions of price, quality, and value: A means-end model and synthesis of evidence. Journal of Marketing, 52(3), 2-22. http://dx.doi.org/10.2307/1251446

Zeithaml, V., Berry, L.L., \& Parasuraman, A. (1996). The behavioral consequences of service quality. Journal of Marketing, 60(2), 31-46. http://dx.doi. org/10.2307/1251929 


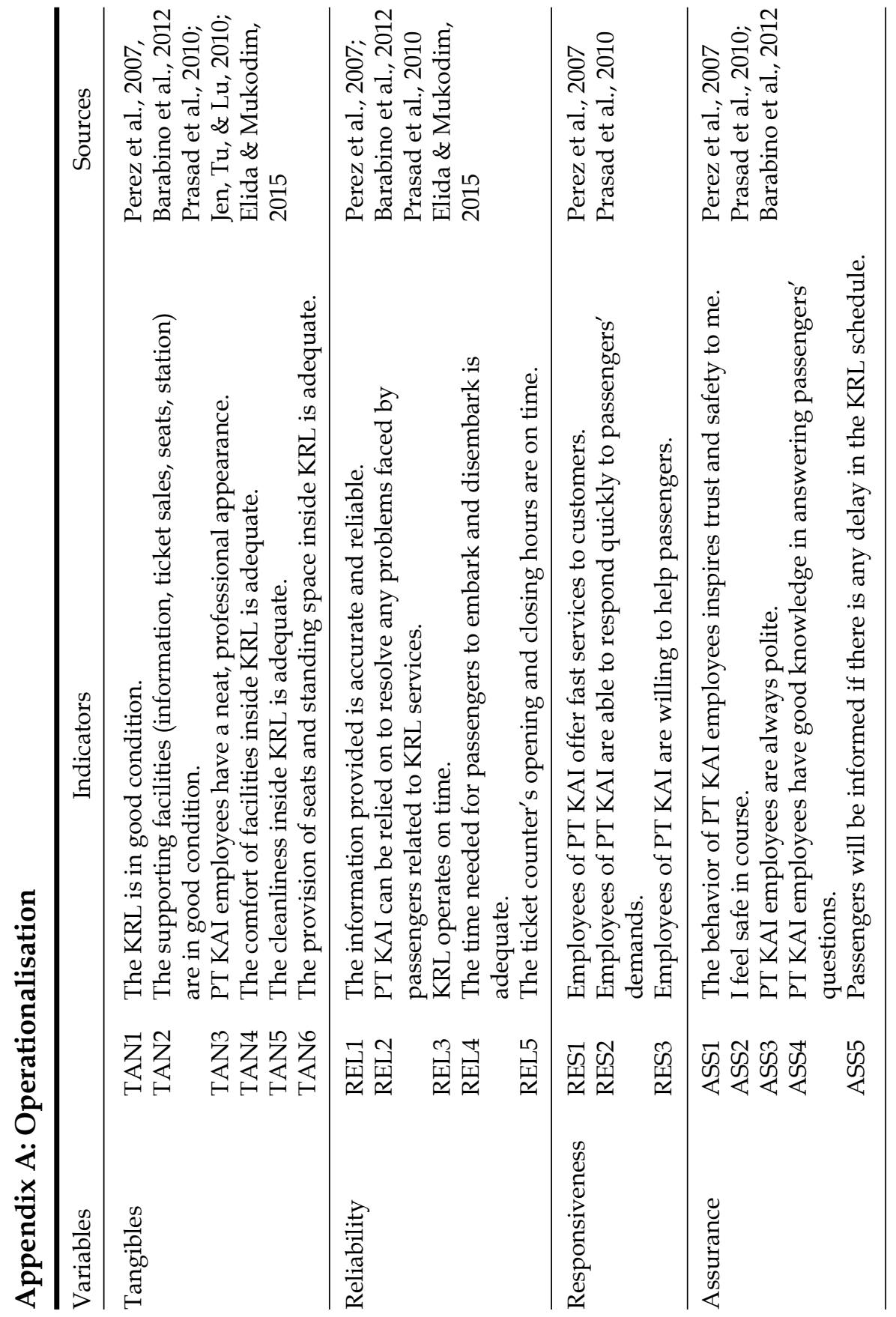


Savira Miranti Ansory and Anya Safira

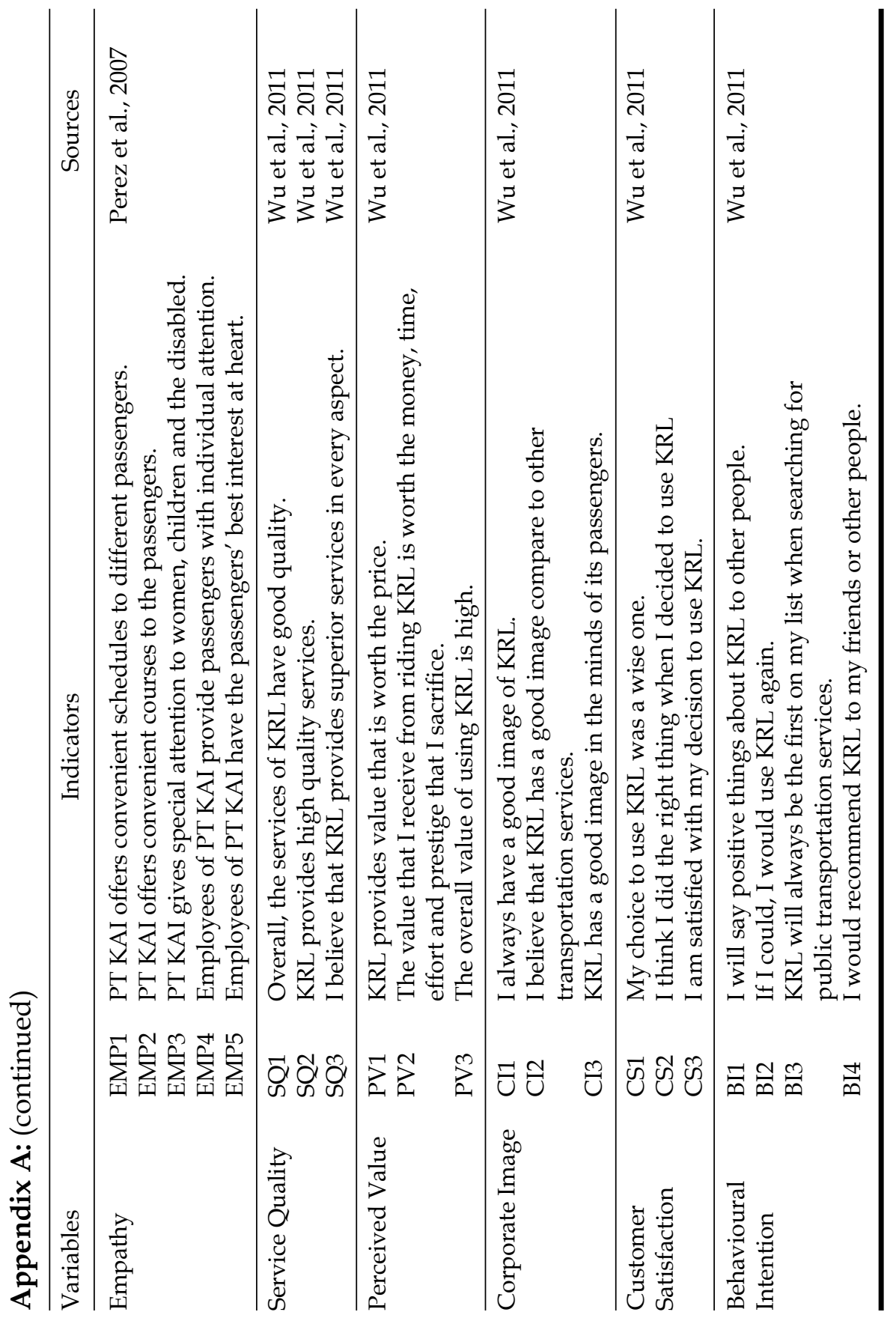

